Article

\title{
Spatial Competition in the Iowa Corn Market: Informing the Pricing Behavior of Corporate and Cooperative Grain Merchants
}

\author{
Jasper Grashuis ${ }^{(1)}$ \\ Division of Applied Social Sciences, University of Missouri, Columbia, MO 65211, USA; grashuisj@missouri.edu \\ Received: 25 January 2019; Accepted: 14 February 2019; Published: 15 February 2019 \\ check for
updates
}

\begin{abstract}
We study spatial competition in the agricultural input procurement sector by explaining variability in corn cash price offers from grain merchants in Iowa. While rail access, river access, size, and ethanol production exhibit the expected positive relationships to corn cash prices, the impact of ownership structure (corporate or cooperative) is complex. Taking distance-based and density-based approaches to spatial competition, we find corporate and cooperative grain merchants differ in their pricing behavior when confronted with spatial competitors. Consistent with theoretical expectations, cooperative grain merchants play a yardstick role in relation to both corporate and cooperative grain merchants.
\end{abstract}

Keywords: spatial competition; agricultural cooperative; imperfect competition; firm behavior

\section{Introduction}

Producers of farm outputs are dispersed across a vast space. As the outputs are often bulky and perishable, the associated cost of transportation to buyers is considerable. The geographic size of the market is therefore effectively reduced to a few buyers in the local or regional market, which introduces a spatial component to competition in agricultural input procurement [1,2]. Indeed, many ratios indicate the presence of monopsonies and oligopsonies in agriculture [3], in particular at the local level [4].

Under imperfect competition in the local or regional market, sellers may be susceptible to spatial price discrimination. If so, the difference in the prices offered by spatial competitors at two separate locations is not explained by the cost of transportation [5]. Instead, buyers of farm outputs use discriminatory pricing to exert local market power. Oligopsony power is manifested by various pricing strategies, but mill pricing is arguably the most common with each seller receiving the same price regardless of distance. As such, the cost of transportation is borne by the seller, not the buyer.

Spatial price discrimination is of great current interest considering the fragile position of farm producers in the agri-food value chain [6]. Many farm producers have been able to protect and enhance their position by forming and joining cooperatives, which have been successful and even dominant in many sectors of the European and North American agri-food industries [7,8]. Nonetheless, the farm share of the food dollar continues to decrease, and the community is encouraged to improve transparency and reduce information asymmetry to limit spatial price discrimination [6].

In contrast to the vast literature on international trade [9], applied research on the topic of spatial price competition in local and regional agri-food environments is relatively scarce. Even the grain sector, which is an integral part of the global food market, has not received much empirical attention from a spatial perspective at the micro-level (i.e., local or regional). Two notable exceptions are Davis and Hill [10] and Campbell and Schmiesing [11], who explored explanations for variability in cash prices at local grain elevators in the Midwest of the United States. While important, these studies 
are now outdated considering recent developments in the grain sector, such as increases in vertical coordination and industry concentration $[4,12]$, which may impact the pricing behavior of grain merchants in relation to grain producers.

Considering the above, we perceive a considerable gap in our collective understanding of spatial price competition in local grain markets. Our research question is as follows: What are possible explanations for variability in corn cash prices in Iowa? We approach our research question by investigating grain merchant and spatial competition characteristics in relation to 589 observations of corn cash prices in Iowa. Iowa, which had the largest production of corn in the United States at 2.6 billion bushels in 2017, is an interesting case study considering the relatively large number of buyers and sellers.

Our contribution to the literature is threefold. First, recent studies of spatial price competition in the agricultural input procurement market have been limited primarily to the dairy industry $[13,14]$. Our study produces the first evidence of spatial price competition in the grain sector since Davis and Hill [10] and Campbell and Schmiesing [11]. Second, like Boone and Özcan [15], our study illustrates the importance of considering the interaction effect of ownership structure and strategic behavior in comparative case studies of cooperatives and non-cooperatives. While cooperative grain merchants on average offered relatively low corn cash prices, the difference in pricing behavior is explained in part by the interaction between the ownership structures of grain merchants and its spatial competitors. Third, while there is already evidence in the prior literature of the yardstick effect of cooperatives on non-cooperatives [16], our study proves the effect also applies to other cooperatives. Instead of colluding or cooperating, the result indicates grain marketing cooperatives engage in stiff price-based competition to secure corn supplies by exploiting spatial characteristics.

We proceed as follows. Section 2 describes the methodology behind the empirical study. We present the data and the variables in Section 3. We discuss the results in Section 4, and we conclude in Section 5 .

\section{Methodology}

Although the objective of the study is to investigate spatial price competition, the specification of a spatial model is not practical or appropriate for the following three reasons: (i) common diagnostics reject the presence of spatial dependence in Iowa corn prices, (ii) the scalar parameters in trial estimations of the spatial lag model, the spatial error model, and the spatial Durbin model did not exhibit statistical significance, and (iii) the inclusion of two spatial weight matrices to model spatial price dependency in relation to corporate and cooperative grain merchants is impossible in the same model. Therefore, we instead specify an ordinary least squares (OLS) model with custom spatial variables to investigate spatial price competition among grain merchants in Iowa.

The basic model is specified as

$$
y_{i}=\alpha+\beta x_{i}+\tau p_{i}+\varphi z_{i}+\varepsilon_{i}
$$

where $y$ is the corn cash price offered by the grain merchant $i, x$ is the vector of grain merchant characteristics, $p$ is the vector of spatial competition characteristics, $\mathrm{z}$ is the vector of control variables, $\varepsilon$ is the stochastic term with a mean zero and variance one, and $\beta, \tau$, and $\vartheta$ are the unknown parameters to be estimated.

Of primary interest to the empirical study is vector $p$. As will be further explained in the next section, we take distance and density-based perspectives of spatial competition. In addition, we also explore the heterogeneous grain pricing behavior of corporate and cooperative grain merchants in relation to other nearby corporate and cooperative grain merchants by means of interaction terms, as in:

$$
\begin{gathered}
y_{i}=\alpha+\beta x_{i}+\tau_{1}(\operatorname{coop} \times \operatorname{coop})+\tau_{2}(\operatorname{coop} \times \text { firm })+\tau_{3}(\text { firm } \times \operatorname{coop}) \\
+\tau_{4}(\text { firm } \times \text { firm })+\varphi z_{i}+\varepsilon_{i}
\end{gathered}
$$


where each symbol and subscript is as before. The exact composition of the vectors is explained in the next section. The analysis is conducted in Stata 15.

\section{Data and Variables}

\subsection{Outcome Variable}

The point of departure is the list of 314 licensed grain merchants of the Grain Warehouse Bureau at the Iowa Department of Agriculture and Land Stewardship. By definition, a licensed grain merchant is an individual or organisation that purchases at least 1000 bushels (one bushel $=56$ pounds $=25.4 \mathrm{~kg}$ ) of grain per month from producers in Iowa.

We collected information from 148 merchants in Iowa offering a cash price for No. 2 yellow corn on Friday, October 5, 2018. Early October is in the midst of the corn harvest season. We collected most of the information from the websites of the merchants. In some instances, we collected information by phone. We also used GeoGrain, which maintains a database of commodity cash bid data, to supplement and corroborate our information. In total, we recorded corn cash price offers at 589 locations. The statistical distribution of the data is illustrated in Figure 1. For the sake of reference, the most relevant corn futures quote was $\$ 3.682$ (ZCZ18), which represents the price for corn to be delivered in December 2018. Figure 2 presents the geographical distribution of the 589 corn cash price observations.

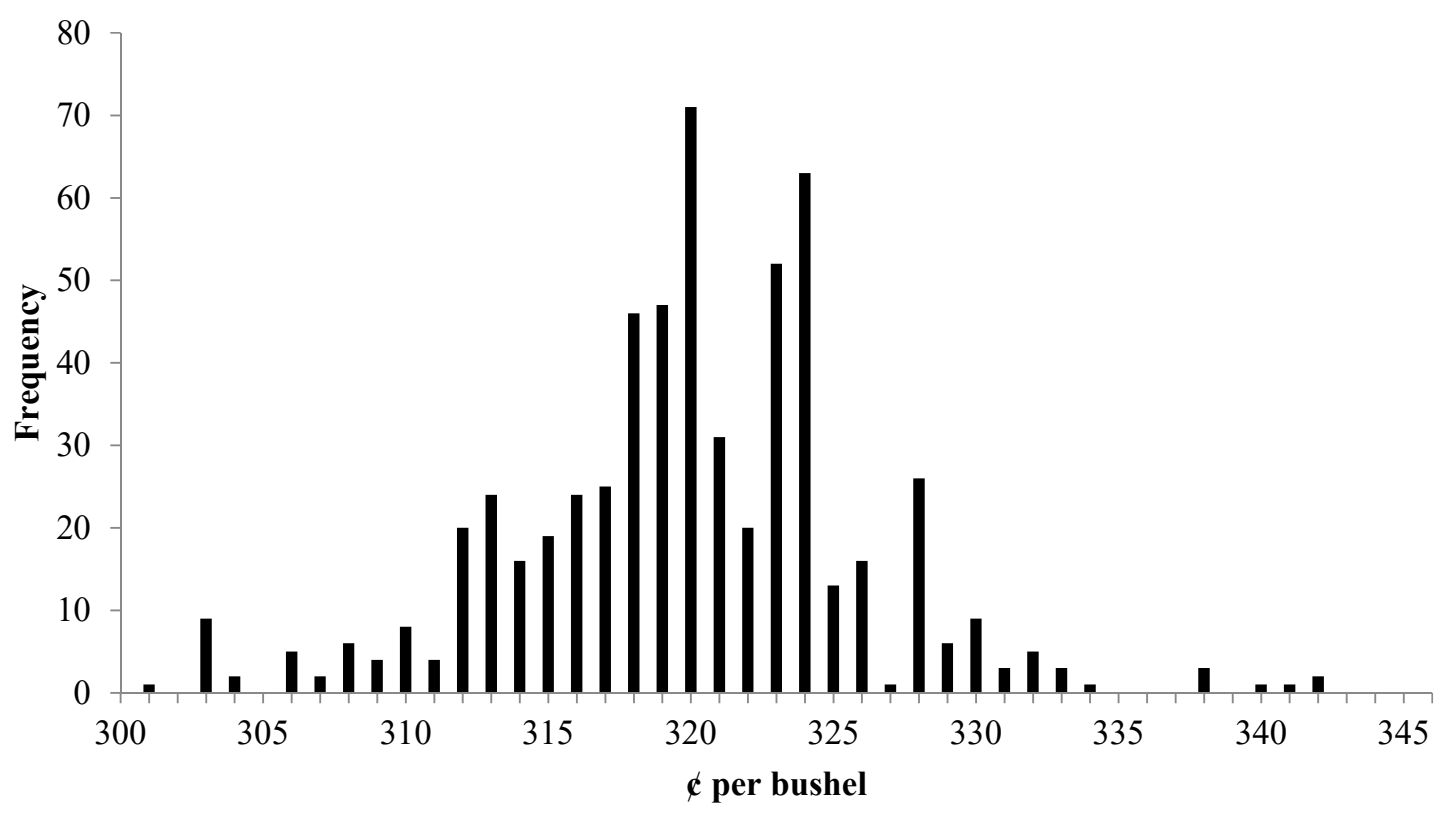

Figure 1. Distribution of 589 Corn Cash Prices in Iowa on October 5, 2018. 


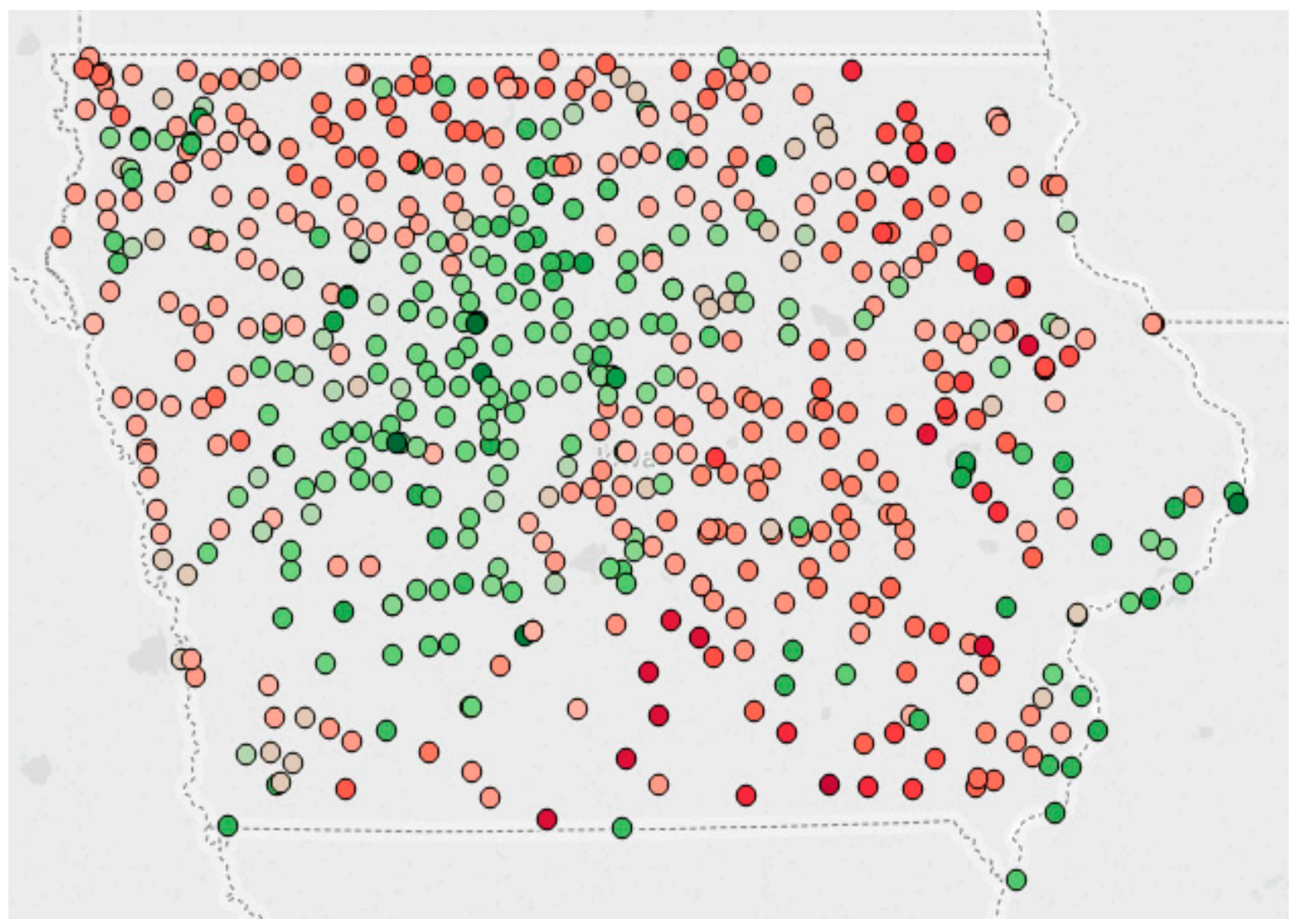

Figure 2. Geographical Distribution of 589 Corn Cash Prices in Iowa on October 5, 2018 *. *A green circle represents an above-average price, and a red circle a below-average price. The darker the color, the further the distance from the average $(\$ 3.1987 /$ bushel $)$.

\subsection{Grain Merchant Characteristics}

\subsubsection{Ownership Structure}

The consideration of ownership structures is important as cooperatives and non-cooperatives have different objectives. While the stereotypical firm is a profit maximizer, most cooperatives have mixed and competing objectives with many parameters and constraints [17,18]. Notably, cooperatives are often formed in times of imperfect competition to force non-cooperatives to stay or become honest [1]. The relationship of cash prices to the absence and presence of cooperatives has been studied previously in the empirical literature [19], but the overall evidence is scarce [16].

We created a binary variable to denote the ownership structure of the grain merchant. We consider two forms: cooperatives and corporations, where the latter is composed of sole proprietorships, partnerships, limited liability companies, or corporations (i.e., non-cooperatives). Fifty-four of the 148 merchants in our database are owned collectively by organized farm producers (see Table 1). However, cooperatives operate most of the grain merchant locations in the state of Iowa (404 of 589). 
Table 1. Summary Statistics.

\begin{tabular}{|c|c|c|c|}
\hline Variable & Mean & Median & S.D. \\
\hline \multicolumn{4}{|l|}{ Outcome Variable } \\
\hline Corn Cash Price (cents/bu) & 319.87 & 320.00 & 6.08 \\
\hline \multicolumn{4}{|l|}{ Grain Merchant Characteristics } \\
\hline Cooperative & 0.69 & 1.00 & 0.46 \\
\hline Rail Access & 0.49 & 0.00 & 0.50 \\
\hline River Access & 0.03 & 0.00 & 0.16 \\
\hline Number of Locations & 18.09 & 9.00 & 21.95 \\
\hline Ethanol Plant & 0.06 & 0.00 & 0.24 \\
\hline \multicolumn{4}{|l|}{ Spatial Competition Characteristics } \\
\hline Distance to Nearest Competitor $(\mathrm{km})$ & 10.16 & 9.81 & 6.00 \\
\hline Distance to Nearest Cooperative $(\mathrm{km})$ & 14.34 & 12.49 & 8.91 \\
\hline Distance to Nearest Firm (km) & 16.61 & 15.50 & 10.06 \\
\hline Number of Competitors within $15 \mathrm{~km}$ & 1.98 & 2.00 & 1.70 \\
\hline Number of Cooperatives within $15 \mathrm{~km}$ & 1.20 & 1.00 & 1.27 \\
\hline Number of Firms within 15 km & 0.77 & 0.00 & 1.03 \\
\hline \multicolumn{4}{|l|}{ Control Variables } \\
\hline Northwest & 0.19 & 0.00 & 0.39 \\
\hline North Central & 0.14 & 0.00 & 0.35 \\
\hline Northeast & 0.11 & 0.00 & 0.31 \\
\hline West Central & 0.14 & 0.00 & 0.35 \\
\hline Central & 0.19 & 0.00 & 0.39 \\
\hline East Central & 0.07 & 0.00 & 0.26 \\
\hline Southwest & 0.04 & 0.00 & 0.21 \\
\hline South Central & 0.04 & 0.00 & 0.21 \\
\hline Southeast & 0.07 & 0.00 & 0.25 \\
\hline Planted Acreage of Corn in County $(\times 1000)$ & 159.39 & 167.50 & 51.30 \\
\hline
\end{tabular}

\subsubsection{Rail or Barge Access}

While trucking is the dominant mode of transportation between the farm and the elevator, access to railroads and rivers at grain merchant locations is important to facilitate more cost-efficient transportation to non-local markets [20]. The ability to transport corn by rail or barge may indicate opportunities to lower the price due to cost efficiency or to increase the price because of improved market access.

Informed by satellite imagery (i.e., Google Maps), immediate access to a railroad or the Mississippi River on the eastern border or the Missouri River on the western border is denoted by binary variables. Almost half of the grain merchant locations in Iowa have rail access. Only 16 of the observed grain merchant locations have immediate access to the river. Twelve of these 16 grain merchant locations also have rail access.

\subsubsection{Firm Size}

Firm size is often associated with superior financial performance by facilitating market access and scale efficiency [21]. The operation of multiple locations within a geographic area may constitute an entry barrier to potential competitors and thus facilitate spatial price discrimination. At the same time, however, relatively large grain merchants may operate in non-local market environments and thus face increased price-based competition from both cooperatives and non-cooperatives, which implies a lower capacity to discriminate by price.

In the absence of detailed survey data on capacity, the size of each grain merchant is indicated by the number of locations. Of the 148 merchants in our database, only 79 have a single location. Furthermore, 125 of the 148 merchants have five or fewer locations, which implies the competitive landscape is shaped by many small and few large buyers. 


\subsubsection{Ethanol Producer}

Driven by the Renewable Fuel Standard, ethanol producers are large buyers of corn and therefore have a positive impact on local prices [22,23]. Proximity to an ethanol plant is also associated with higher land values [24]. According to the Iowa Renewable Fuels Association, 43 bio-ethanol producers existed in the state of Iowa at the time of the study. We created a binary variable to denote if the grain merchant is an ethanol producer.

\subsection{Spatial Competition Characteristics}

The degree of spatial competition in the Iowa corn market is informed by two types of variables. Following Alvarez et al. [13], who studied oligopsony power in the milk procurement market of Asturias, Spain, we take both a density-based and a distance-based approach to model the spatial character of competition. Consistent with our objective of studying the interaction between grain merchant and spatial competition characteristics, we also differentiate between cooperative and corporate grain merchants. Each variable excludes all other locations by the same owners. Also, the state of Iowa is treated as an isolated location, which implies observations across the border are not considered as competitors.

\subsection{Control Variables}

We address heterogeneity in the external environment with two types of control variables. First, we create a series of binary variables for the nine districts used by USDA-NASS. Second, we account for the local supply of corn by including the total amount of planted acreage of corn by county.

\section{Results}

Corresponding to Equation (1), we first present two models with a distance-based approach to spatial competition, and then two models with a density-based approach. For each approach, we present a model without, and then with consideration of ownership structures (i.e., corporate or cooperative grain merchant). Then, corresponding to Equation (2), we proceed to an interaction model to not only consider the ownership structures of the competitors but also the ownership structures of the observations, thus studying the possibility of heterogeneous spatial price behavior.

\subsection{Spatial Price Competition-Distance}

As per the results, we observe a significant relationship of grain merchant characteristics to corn cash prices (see Table 2). Rail and river access both positively relate to the cash price by magnitudes of $₫ 1.21-1.33$ and $₫ 6.72-8.06$ per bushel. The result is comparable to Davis and Hill [10], who found barge shipment capabilities had a positive impact of $₫ 4.50$ per bushel on corn cash prices in Illinois. While measured differently, Davis and Hill [10] also reported a positive relationship of rail access to corn cash prices. Our result indicates grain merchants with an ability to transport by rail or barge offer higher cash prices to input suppliers. The premium is likely facilitated by improvements in market access and scale efficiency. The ensuing improvement in the operating margin of the grain merchant is then in part transferred to the corn producer.

In addition, organisational size, which is indicated by the total number of locations, is estimated to positively relate to corn cash prices. Each additional location is associated with a $₫ 0.05$ increase in the corn cash price. With 18 locations, the average grain merchant in the sample is therefore able to offer almost $\$ 0.01$ per bushel more as compared to grain merchants with only a single location. The result is sensible from an economic perspective as the ability to lower the average cost of production to the minimum is predicated on size, suggesting an increase in labour and capital produces an even greater increase in output. Also, while increasing the service territory with more locations, grain merchants may be able to spread the existing cost of contracting, transporting, and other related expenses. Generally, our result corroborates prior findings by Schroeder [25] and Ariyaratne et al. [26] 
regarding the superior scale efficiency of relatively large grain marketing cooperatives. In addition, our result constitutes evidence of the main motivation behind the ongoing consolidation among grain marketing cooperatives in the United States [27]. The prolific merger and acquisition activity is driven by the need to improve efficiency so as to remain relevant to relatively large buyers.

Table 2. Determinants of Corn Cash Prices-Distance-Based Models.

\begin{tabular}{|c|c|c|}
\hline & Distance Model 1 & Distance Model 2 \\
\hline Intercept & $\begin{array}{l}318.348^{* * *} \\
(1.320)\end{array}$ & $\begin{array}{l}318.210 * * * \\
(1.400)\end{array}$ \\
\hline \multicolumn{3}{|l|}{ Grain Merchant Characteristics } \\
\hline Cooperative & $\begin{array}{l}-1.039 \\
(0.697)\end{array}$ & $\begin{array}{l}-1.045 \\
(0.689)\end{array}$ \\
\hline Rail Access & $\begin{array}{l}1.213^{* *} \\
(0.471)\end{array}$ & $\begin{array}{l}1.333^{* * *} \\
(0.467)\end{array}$ \\
\hline River Access & $\begin{array}{l}6.723 \text { *** } \\
(2.108)\end{array}$ & $\begin{array}{l}8.064^{* * *} \\
(2.171)\end{array}$ \\
\hline Number of Locations & $\begin{array}{l}0.049^{* * *} \\
(0.012)\end{array}$ & $\begin{array}{l}0.053^{* * *} \\
(0.012)\end{array}$ \\
\hline Ethanol Producer & $\begin{array}{l}6.087^{* * *} \\
(1.168)\end{array}$ & $\begin{array}{l}6.168^{* * *} \\
(1.188)\end{array}$ \\
\hline \multicolumn{3}{|l|}{ Spatial Competition Characteristics } \\
\hline Distance to Nearest Competitor & $\begin{array}{l}-0.116^{* *} \\
(0.048)\end{array}$ & \\
\hline Distance to Nearest Cooperative & & $\begin{array}{l}-0.102^{* * *} \\
(0.033)\end{array}$ \\
\hline Distance to Nearest Firm & & $\begin{array}{l}0.006 \\
(0.031)\end{array}$ \\
\hline Control Variables & Included & Included \\
\hline $\mathrm{N}$ & 589 & 589 \\
\hline $\mathrm{F}$ & 12.51 & 12.36 \\
\hline $\mathrm{R}^{2}$ & 0.28 & 0.29 \\
\hline
\end{tabular}

Corresponding to McNew and Griffith [22], we also find a positive and significant relationship of ethanol production to corn cash prices. On average, ethanol producers offer $₫ 6.09-6.17$ per bushel more as compared to other grain merchants. Our estimate is within the $\$ 4.63-19.33$ range of the estimated price impact at ethanol production sites in the study by McNew and Griffith [22], which included observations from Iowa. The premium is in part established by the tax credit offered by the US government to corn ethanol producers. The tax credit enables ethanol producers to bid more aggressively on the local market to secure enough supply to operate at capacity. In general, our result indicates the presence of ethanol producers, which are high-volume consumers of corn, increases the quantity demanded and thus drives the equilibrium price of corn in the local market upward.

In terms of spatial competition, we first include the variable that measures the distance to the nearest competitor, regardless of the ownership structure. Per the estimate, the cash price offered by the average grain merchant decreases by $₫ 0.12$ per bushel as the distance to the nearest competitor increases by one kilometer. The further the nearest competitor, the lower the cash price offered. The significant result is indicative of spatial price discrimination by grain merchants. The nearest competitor is at a distance of 10.16 kilometers for the average grain merchant in Iowa, which implies an ability to discriminate by approximately $₫ 1.20$ per bushel. Economically, an amount of $\notin 1.20$ per bushel is not trivial. Assuming an average yield of 200 bushels per acre, the per acre impact of price discrimination amounts to $\$ 2.40$.

However, as illustrated by the second distance-based model, it is imperative to also consider the ownership structure of the nearest competitor. Per the results, the distance to the nearest corporate 
grain merchant is inconsequential to the pricing behavior of the average grain merchant. Instead, what matters is the distance to the nearest cooperative grain merchant. For each kilometer separating the average grain merchant and the nearest cooperative grain merchant, the corn cash price decreases by $\not 0.10$ per bushel. Our result is evidence of the yardstick role performed by cooperatives in the case of imperfect competition to limit the monopsony or oligopsony power of non-cooperatives [1]. In doing so, grain marketing cooperatives have a positive impact on the welfare of local grain producers.

\subsection{Spatial Price Competition-Density}

When changing the measurement of spatial competition from distance to density, we observe the same results as before (see Table 3). The magnitude of the estimated impact of the grain merchant characteristics (i.e., rail access, river access, size, ethanol producer) on the corn cash price is similar. The interpretation of the relationship of grain merchants and spatial competitors to corn cash prices is also similar. First, without consideration of the ownership structure, we observe a positive impact of competitors within a $15-\mathrm{km}$ radius on the corn cash price. For each additional competitor within a $15-\mathrm{km}$ radius of the average grain merchant, the corn cash price increases by $\phi 0.54$ per bushel. Thus, the denser the competition in the local market, the higher the corn cash price offered. Once again, however, we must consider the ownership structure as the pricing behavior of the average grain merchant is different in relation to corporate grain merchants and cooperative grain merchants. On average, grain merchants do not adjust corn cash prices in response to the presence of corporate grain merchants within a $15-\mathrm{km}$ radius. In the case of cooperative grain merchants, however, the corn cash price is estimated to increase by $₫ 1.01$ per bushel. The density-based model thus corroborates the finding produced by the distance-based model.

Table 3. Determinants of Corn Cash Prices-Density-Based Models.

\begin{tabular}{|c|c|c|}
\hline & Density Model 1 & Density Model 2 \\
\hline Intercept & $\begin{array}{l}316.002^{* * *} \\
(1.340)\end{array}$ & $\begin{array}{l}315.677^{* * *} \\
(1.317)\end{array}$ \\
\hline \multicolumn{3}{|l|}{ Grain Merchant Characteristics } \\
\hline Cooperative & $\begin{array}{l}-0.901 \\
(0.707)\end{array}$ & $\begin{array}{l}-0.597 \\
(0.710)\end{array}$ \\
\hline Rail Access & $\begin{array}{l}1.333^{* * *} \\
(0.461)\end{array}$ & $\begin{array}{l}1.393^{* * *} \\
(0.456)\end{array}$ \\
\hline River Access & $\begin{array}{l}7.206^{* * *} \\
(2.035)\end{array}$ & $\begin{array}{l}7.402 * * * \\
(1.987)\end{array}$ \\
\hline Number of Locations & $\begin{array}{l}0.050 * * * \\
(0.012)\end{array}$ & $\begin{array}{l}0.053^{* * *} \\
(0.012)\end{array}$ \\
\hline Ethanol Producer & $\begin{array}{l}6.055^{* * *} \\
(1.159)\end{array}$ & $\begin{array}{l}6.008^{* * *} \\
(1.160)\end{array}$ \\
\hline \multicolumn{3}{|c|}{ Spatial Competition Characteristics } \\
\hline \# of Competitors-15 km & $\begin{array}{l}0.535^{* * *} \\
(0.146)\end{array}$ & \\
\hline \# of Cooperatives-15 km & & $\begin{array}{l}1.006^{* * *} \\
(0.202)\end{array}$ \\
\hline \# of Corporations-15 km & & $\begin{array}{l}-0.077 \\
(0.224)\end{array}$ \\
\hline Control Variables & Included & Included \\
\hline $\mathrm{N}$ & 589 & 589 \\
\hline $\mathrm{F}$ & 13.37 & 12.86 \\
\hline $\mathrm{R}^{2}$ & 0.29 & 0.30 \\
\hline
\end{tabular}

Statistical significance at the $99 \%$ confidence level is denoted by ${ }^{* * *}$. 


\subsection{Spatial Price Competition-Interaction}

Finally, in relation to Equation (2), we discuss the results of two models in which we use the interaction terms to estimate the pricing behavior of corporate and cooperative grain merchants in response to spatial competition by other corporate and cooperative grain merchants (see Table 4). We thus consider the ownership structure of the spatial competitor as well as the grain merchant.

Table 4. Determinants of Corn Cash Prices-Interaction Models.

\begin{tabular}{|c|c|c|}
\hline & Interaction-Distance & Interaction-Density \\
\hline Intercept & $\begin{array}{l}319.945^{* * *} \\
(1.591)\end{array}$ & $\begin{array}{l}314.974^{* * *} \\
(1.509)\end{array}$ \\
\hline \multicolumn{3}{|l|}{ Grain Merchant Characteristics } \\
\hline Cooperative & $\begin{array}{l}-4.078^{* * *} \\
(1.468)\end{array}$ & $\begin{array}{l}0.385 \\
(1.035)\end{array}$ \\
\hline Rail Access & $\begin{array}{l}1.400 * * * \\
(0.467)\end{array}$ & $\begin{array}{l}1.391 \text { *** } \\
(0.455)\end{array}$ \\
\hline River Access & $\begin{array}{l}8.021^{* * *} \\
(2.299)\end{array}$ & $\begin{array}{l}7.729 * * * \\
(2.057)\end{array}$ \\
\hline Number of Locations & $\begin{array}{l}0.054^{* * * *} \\
(0.012)\end{array}$ & $\begin{array}{l}0.052 * * * \\
(0.012)\end{array}$ \\
\hline Ethanol Producer & $\begin{array}{l}6.179 * * * \\
(1.161)\end{array}$ & $\begin{array}{l}5.944^{* * *} \\
(1.152)\end{array}$ \\
\hline \multicolumn{3}{|l|}{ Spatial Competition Characteristics } \\
\hline Cooperative ${ }^{*}$ Cooperatives & $\begin{array}{l}-0.078^{* *} \\
(0.039)\end{array}$ & $\begin{array}{l}0.867 \text { *** } \\
(0.228)\end{array}$ \\
\hline Cooperative ${ }^{*}$ Corporations & $\begin{array}{l}0.059 * \\
(0.034)\end{array}$ & $\begin{array}{l}-0.248 \\
(0.236)\end{array}$ \\
\hline Corporation ${ }^{*}$ Cooperatives & $\begin{array}{l}-0.114^{\text {** }} \\
(0.056)\end{array}$ & $\begin{array}{l}1.191 \text { *** } \\
(0.362)\end{array}$ \\
\hline Corporation $*$ Corporations & $\begin{array}{l}-0.109^{* *} \\
(0.055)\end{array}$ & $\begin{array}{l}0.352 \\
(0.465) \\
\end{array}$ \\
\hline Control Variables & Included & Included \\
\hline $\mathrm{N}$ & 589 & 589 \\
\hline $\mathrm{F}$ & 11.47 & 11.56 \\
\hline $\mathrm{R}^{2}$ & 0.30 & 0.31 \\
\hline
\end{tabular}

Statistical significance at the $90 \%, 95 \%$, and $99 \%$ confidence levels is denoted by ${ }^{*}, * *$, and ${ }^{* * *}$, respectively.

In doing so, we reveal corporate and cooperative grain merchants respond differently to spatial competitors. In the distance-based model, cooperative grain merchants lower corn cash prices by $\not 0.08$ per bushel as the distance to the nearest cooperative grain merchant increases by one kilometer. The distance to the nearest corporate grain merchant is determined to have no significant relationship to its pricing behavior. Corporate grain merchants, however, do not appear to consider the ownership structure of their nearest competitor as the change in pricing behavior is identical as the distance increases. For each additional kilometer in the distance to the nearest competitor, the average corporate grain merchant decreases the corn cash price by $\not 0.11$ per bushel.

The narrative is somewhat different in relation to the density-based model. When counting the total number of corporate grain merchants within a $15-\mathrm{km}$ radius, the corn cash prices offered by both corporate and cooperative grain merchants does not change. Instead, both corporate and cooperative grain merchants only respond to the intensification of local competition by cooperative grain merchants. The average cooperative grain merchant increases the corn cash price by $\notin 0.87$ per bushel in response to each additional cooperative grain merchant within a $15-\mathrm{km}$ radius. The response by the average corporate grain merchant is even greater in magnitude at $\$ 1.19$ per bushel. For the sake 
of comparison, the original density-based model without consideration of the ownership structure of the grain merchant yielded an estimate of $\$ 1.01$ per bushel.

Overall, the results of the final distance-based model and the final density-based model yield several observations. First, the pricing behavior of both corporate and cooperative grain merchants is not only influenced by the distance, but also by the density of the local competition. However, the total number of corporate grain merchants may not make a difference. The density-based model should perhaps be preferred to the distance-based model as (i) the goodness-of-fit of the overall density-based model is greater, and (ii) the spatial variables in the distance-based model are only significant at the 95\% confidence level and not the 99\% confidence level. Second, cooperatives do not only perform a yardstick role for non-cooperatives but also other cooperatives. Competition among cooperatives is contrary to the foundational values and principles of cooperatives, which includes cooperation among cooperatives. Price-based competition among grain marketing cooperatives likely contributes to the recent uptick in merger and acquisition activity. Third, while there is significant evidence of spatial price discrimination by non-cooperatives, it is surprising to find cooperatives are also capable of exploiting spatial competition characteristics. The strategic behavior of marketing cooperatives is not explored in great detail in the literature, although recent studies have illustrated how relatively few marketing cooperatives use differentiation to pursue competitiveness [28]. More attention ought to be directed to price-based competition by marketing cooperatives, which strategically is more sensible considering the upstream bias of its members.

In terms of model fitness, however, it is debatable if the final two models are significantly better as compared to the prior models. The relative increase in $\mathrm{R}^{2}$ is modest, suggesting the consideration of heterogeneous pricing behavior by corporate and cooperative grain merchants has not facilitated a vast improvement in explanatory power. Apparently much of the variance in pricing behaviour attributable to spatial competition is already captured by relatively simple conceptualizations of distance and density. Nonetheless, consideration of the ownership structure facilitates a closer approximation of the real world and should arguably be preferred.

\subsection{Sensitivity Analysis}

For the sake of robustness, we conducted additional regressions with different subsamples. First, we studied a sample without ethanol producers $(\mathrm{N}=554)$. We included the distance to the nearest ethanol producer as another indicator of spatial competition. Consistent with McNew and Griffith [22], the variable had a significant negative relationship to the corn cash price. Otherwise, the estimates did not facilitate new or different interpretations. Second, we studied a sample without observations below the fifth percentile or above the 95th percentile $(\mathrm{N}=530)$. The estimates did not facilitate new or different interpretations. Third, we studied a sample without observations within 15 kilometers of the border $(\mathrm{N}=517)$. Again, the estimates did not facilitate new or different interpretations.

We also conducted a series of regressions with different radii for the density-based approach to spatial competition. Figure 3 illustrates the results of model specifications with radii of 10, 20, 30, 40, and 50 kilometers. For the sake of reference, the original density-based model contained a 15-km radius. As the distance of the radius increases, the magnitude of the estimated impact of each additional spatial competitor on the corn cash price decreases. At the same time, the t-statistic associated with each estimate increases. The gradual decrease in magnitude is logical because a larger radius contains a greater number of spatial competitors. The result may imply spatial competitors within a larger radius are still relevant to the pricing behavior of grain merchants but to an increasingly lesser extent. 


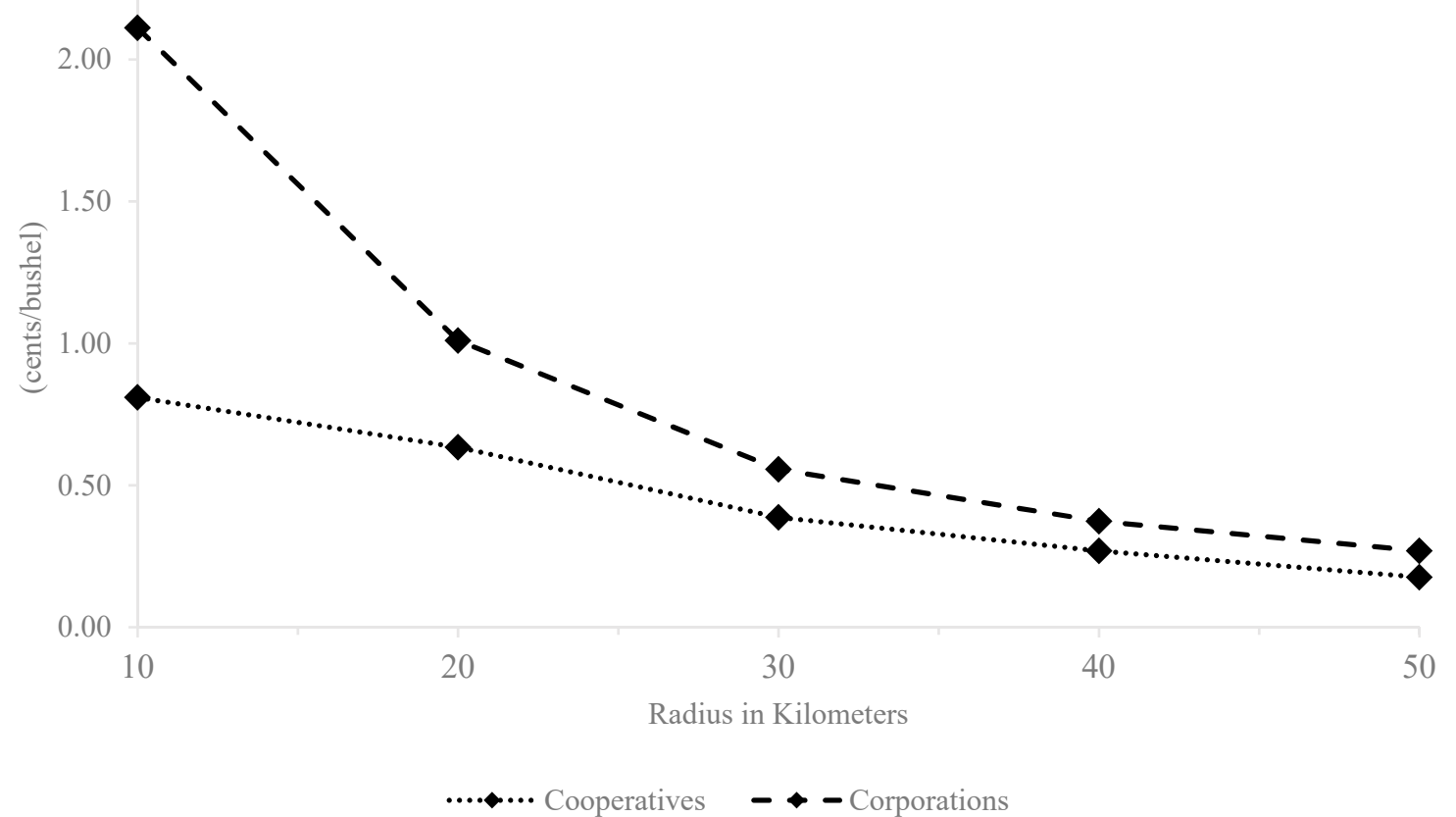

Figure 3. Point Estimates of the Impact of Cooperative Grain Merchants on the Corn Cash Prices of Corporate and Cooperative Grain Merchants with Different Radii.

\section{Conclusions}

Spatial price competition in local or regional grain markets has not received much attention in recent empirical literature. In light of ongoing decreases in farm income, we revisited the issue and produced new evidence with an empirical study of corporate and cooperative grain merchants in Iowa, which is the largest producer of corn in the United States. With 589 observations of corn cash prices observed in the 2018 harvest season, the study emphasized the interaction between grain merchant and spatial competition characteristics.

Whether conceptualizing spatial competition in terms of distance or density, we found evidence of local buyer power by corporate as well as cooperative grain merchants. However, their pricing behavior differed when confronted with corporate or cooperative grain merchants as spatial competitors. Conforming to the yardstick effect, spatial competition by cooperative grain merchants motivated both corporate and cooperative grain merchants to increase corn cash prices. While contributing to the prior literature on the strategic choice and behavior of cooperatives, our study is arguably the first to yield evidence of the yardstick effect of cooperatives in relation to both non-cooperatives and other cooperatives.

Our study has several practical implications. First, cooperative grain merchants may have strong incentives to extend operations to areas in which corporate grain merchants have spatial monopsonies or oligopsonies and exert buyer power in relation to local grain producers. For example, a few corporate grain merchants dominate the southeast corner of the Iowa corn market. The entry of cooperative grain merchants, or perhaps even just the threat of entry, may reduce spatial price discrimination and thus facilitate improvements to the welfare of local grain producers. Second, the establishment of rail or river access may constitute the best opportunities for grain merchants to improve their bidding position on the corn spot market. While immediate access to railroads or rivers is often infeasible, grain merchants may seek indirect access by means of partnerships with truckers or other merchants. Where possible, grain merchants may also pursue organisational growth through the establishment of more locations to achieve scale economies. Third, the evidence of the yardstick effect of cooperatives is justification for the policy support. Often characterized as inefficient, it is clear that grain marketing cooperatives force improvements in producer welfare in the grain sector and thus provide ex-ante production incentives to grain producers. Therefore, policymakers may consider tax credits and other 
policy measures to incentivize grain marketing cooperatives to extend service coverage to areas in which corporate grain merchants exert buyer power. Fourth, the discriminatory pricing behavior of grain merchants is concerning as the spot market in the corn sector is often characterized as efficient with relatively many buyers and sellers. In the absence of an efficient spot market, producers of other commodities may face an even higher degree of spatial price discrimination if other mechanisms of price discovery are not available. In the interest of both producer and consumer welfare, policymakers may further investigate opportunities to limit the negative consequences of local monopsonies and oligopsonies in the agricultural input procurement market.

We must also note several empirical limitations. First, we treated the state of Iowa as a geographical island without explicit consideration of its neighbouring states. Distances and densities of spatial competition may therefore have been underestimated for observations near the borders. Second, we collected the corn cash price observations on one day. Taking an average over a longer time period, such as one month or one year, may have eliminated the impact of random aberrations in pricing decisions (e.g., inclement weather, equipment malfunctions). Third, our findings cannot be generalized to other regions or commodities. Future research is needed to determine if the pricing behavior of cooperatives and non-cooperatives is similar in, for example, the soybean market of Minnesota or the livestock market of Kansas.

The current state of the empirical literature on spatial competition in the agricultural input procurement market is not strong, but many opportunities to generate knowledge exist to inform recommendations for practitioners and policymakers. For example, future research may address if corporate and cooperative grain merchants exhibit the same pricing behavior (i) during the off-season, (ii) in other states with less corn production, or (ii) in relation to non-spot market transactions (i.e., contracts)? In terms of producer welfare, what degree of spatial price discrimination will farm producers endure before engaging in group action? And what is the impact of the current regulation on the ability of local monopsonists and oligopsonists to exert buyer power in relation to farm producers? Answers to such questions may be addressed by different methodologies, including the many recent advances in spatial econometrics $[29,30]$.

Funding: This research received no external funding.

Conflicts of Interest: The author declares no conflict of interest.

\section{References}

1. Sexton, R.J. Imperfect competition in agricultural markets and the role of cooperatives: A spatial analysis. Am. J. Agric. Econ. 1990, 72, 709-720. [CrossRef]

2. Fackler, P.L.; Goodwin, B.K. Spatial price analysis. In Handbook of Agricultural Economics, Volume 1; Elsevier: Amsterdam, the Netherlands, 2001; pp. 971-1024.

3. McCorriston, S. Why should imperfect competition matter to agricultural economists? Eur. Rev. Agric. Econ. 2002, 29, 349-371. [CrossRef]

4. Saitone, T.L.; Sexton, R.J. Concentration and consolidation in the us food supply chain: The latest evidence and implications for consumers, farmers, and policymakers. Federal Reserve Bank Kans., Econ. Rev. 2017, 102, $25-59$.

5. Phlips, L. The Economics of Price Discrimination; Cambridge University Press: Cambridge, UK, 1983.

6. European Union Council. Strengthening Farmers' Position in the Food Supply Chain and Tackling Unfair Trading Practices; EU Council Outcome of Proceedings 15508; European Union: Brussels, Belgium, 2016.

7. Cooperatives Europe. The Power of Cooperation; Cooperatives Europe: Brussels, Belgium, 2016.

8. U.S. Department of Agriculture. Cooperative statistics 2016. In Rural Development Service Report 80; U.S. Department of Agriculture: Washington, DC, USA, 2017.

9. Conforti, P. Price transmission in selected agricultural markets. In Commodity and Trade Policy Research Working Paper 7; FAO: Rome, Italy, 2004.

10. Davis, L.; Hill, L. Spatial price differentials for corn among Illinois country elevators. Am. J. Agric. Econ. 1974, 56, 135-144. [CrossRef] 
11. Campbell, G.R.; Schmiesing, B.H. Impact of buyer relationships on the performance of local grain elevators. North Cent. J. Agric. Econ. 1979, 1, 39-45. [CrossRef]

12. MacDonald, J.M. Agricultural Contracting Update: Contracts in 2008; Department of Agriculture: Washington, DC, USA, 2011.

13. Alvarez, A.M.; Fidalgo, E.G.; Sexton, R.J.; Zhang, M. Oligopsony power with uniform spatial pricing: Theory and application to milk processing in Spain. Eur. Rev. Agric. Econ. 2000, 27, 347-364. [CrossRef]

14. Graubner, M.; Koller, I.; Salhofer, K.; Balmann, A. Cooperative versus non-cooperative spatial competition for milk. Eur. Rev. Agric. Econ. 2011, 38, 99-118. [CrossRef]

15. Boone, C.; Özcan, S. Strategic choices at entry and relative survival advantage of cooperatives versus corporations in the U.S. bio-ethanol industry, 1978-2015. J. Manag. Stud. 2016, 53, 1113-1140. [CrossRef]

16. Grashuis, J.; Su, Y. A review of the empirical literature on farmer cooperatives: Performance, ownership and governance, finance, and member attitude. Ann. Public Coop. Econ. 2019, 90, 77-92. [CrossRef]

17. Soboh, R.A.; Lansink, A.O.; Giesen, G.; Van Dijk, G. Performance measurement of the agricultural marketing cooperatives: The gap between theory and practice. Rev. Agric. Econ. 2009, 31, 446-469. [CrossRef]

18. Benos, T.; Kalogeras, N.; Wetzels, M.; Ruyter, K.D.; Pennings, J.M. Harnessing a 'currency matrix' for performance measurement in cooperatives: A multi-phased study. Sustainability 2018, 10, 4536. [CrossRef]

19. Jardine, S.L.; Lin, C.Y.C.; Sanchirico, J.N. Measuring benefits from a marketing cooperative in the Copper River fishery. Am. J. Agric. Econ. 2014, 96, 1084-1101. [CrossRef]

20. Nolan, J.; Skotheim, J. Spatial competition and regulatory change in the grain handling and transportation system in western Canada. Ann. Reg. Sci. 2008, 42, 929-944. [CrossRef]

21. Grashuis, J.; Dary, S. Patented innovation and firm value in the us food and drink industry: The economic importance of high-quality product innovation. J. Agric. Food Ind. Organ. 2017. [CrossRef]

22. McNew, K.; Griffith, D. Measuring the impact of ethanol plants on local grain prices. Rev. Agric. Econ. 2005, 27, 164-180. [CrossRef]

23. Fort, C.; Parcell, J. A case study on the impact of an ethanol plant on corn price. J. Am. Soc. Farm Manag. Rural Apprais. 2006, 69, 26-30.

24. Henderson, J.; Gloy, B.A. The impact of ethanol plants on cropland values in the great plains. Agric. Financ. Rev. 2009, 69, 36-48. [CrossRef]

25. Schroeder, T.C. Economies of scale and scope for agricultural supply and marketing cooperatives. Rev. Agric. Econ. 1992, 14, 93-103. [CrossRef]

26. Ariyaratne, C.B.; Featherstone, A.M.; Langemeier, M.R.; Barton, D.G. Measuring X-efficiency and scale efficiency for a sample of agricultural cooperatives. Agric. Resour. Econ. Rev. 2000, 29, 198-207. [CrossRef]

27. Merlo, C. Crossing the merger finish line. In Rural Cooperatives; September/October 2017; Department of Agriculture: Washington, DC, USA, 2017.

28. Grashuis, J. Branding by U.S. farmer cooperatives: An empirical study of trademark ownership. J. Co-op. Organ. Manag. 2017, 5, 57-64. [CrossRef]

29. Arbia, G. Spatial econometrics: A rapidly evolving discipline. Econometrics 2016, 4, 18. [CrossRef]

30. Bhattacharjee, A.; Holly, S.; Mur, J. Contemporary developments in the theory and practice of spatial econometrics. Spat. Econ. Anal. 2018, 13, 139-147. [CrossRef]

(C) 2019 by the author. Licensee MDPI, Basel, Switzerland. This article is an open access article distributed under the terms and conditions of the Creative Commons Attribution (CC BY) license (http://creativecommons.org/licenses/by/4.0/). 